\title{
Diversity of Outcomes Among Adolescent Children of Mothers With Mental IIIness
}

\author{
Carol T. Mowbray, Deborah Bybee, Daphna Oyserman, \\ Paula Allen-Meares, Peter MacFarlane, \\ AND TAMERA HART-JOHNSON
}

When parents have a serious mental illness, it significantly increases the risk of a psychiatric disorder in their children (Erlenmeycr-Kimling et al., 1997; Weissman, Leal, Bruce, 1987). In this postdeinstitutionalization era, a sizeable number of children are likely to grow up with a mother who has a serious mental illness; many of these women are single-handedly carrying out parenting responsibilities (Nicholson, Nason, Calabresi, \& Yando, 1999). Further, as chronic mental illnesses are episodic, with episodes lasting up to 2 years, children of these parents are likely 10 experience more than one episode of parental mental illness influencing more than one developmental phase (Hammen, 1997).

At the same time, developmental research has indicated that not all children who grow up in high-risk situations show adverse outcomes. The term resilience has been used to encompass the "class of phenomena involving successful adaptation in the context of significant threats to development" (Masten et al., 1999, p. 143). Parental mental illness, in fact, does not always produce psychological or other problems for offspring (Arbellect al., 1997; Wals el al., 2001). Some rescarchers have identified subgroups of resilient children-

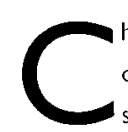
hildren of parents with mental illness are an at-risk population according to research on psychiatric outcomes using White, middle-class samples of depressed parents and infants and preschool children. The current study expands this evidence by exploring within-group heterogeneity across psychosocial outcomes, in a racially diverse, low-income sample of adolescent children of mothers with mental illness $(N=166)$. Using measures of mental health, academics, behavior problems, and social relationships-and employing cluster analysis methodology — we identified five meaningful subgroups of these youth. Two of five identified clusters evidenced mental health symptoms (15\%) or possible behavioral problems (27\%). The largest cluster (30\%) appeared quite socially and academically competent; another cluster $(22 \%)$ presented as average in their functioning but adult-oriented. A final small cluster (4.8\%) was distinguished by members' social isolation. Cluster membership related to maternal substance abuse history, father's relationship to youth, and social support available to mothers. Implications for planning preventive interventions are discussed.

those whose parents have mental illness but who are competent with no mental health problems (Garber \& Little, 1999; Scherer, Melloh, Buyck, Anderson, \& Foster, 1996). Garmezy's (1987, 1993) original theory and research on resilience hypothesized that children's competency relates to psychosocial resources available; whercas children growing up in adversity often have fewer "good" resources available to them. If reasonably adequate resources are present, competency outcomes are generally satisfactory, even in the context of chronic, severe stressors. In research on parents with mental illness and their children, most studies have involved infants or toddlers. Unfortunately, the lcast amount of research has focused on adolescent offspring of parents with mental illness (Oyscrman, Mowbray, AllenMeares, \& Firminger, 2000), who experience more risk factors and also are more likely to have access to psychosocial resources.

\section{Maternal Psychiatric VARIABLES AS PREDICTORS OF ADOLESCENT OUTCOMES}

Research has focused on the link between parental depression and children's mental illness (Boyle \& Pickles, 1997). Adolescent children of parents with affective dis- 
orders have higher rates of diagnosed mental illnesses than do children of nonmentally ill parents (Beardslee, Keller, Lavori, Staley, \& Sacks, 1993; GrigoroiuServanescu, Christodorescu, Totoescu, \& Jipescu, 1991). In fact, by early adulthood, children with a depressed parent have nearly a $50 \%$ chance of experiencing an episode of major depression themselves (Beardslee, Versage, \& Gladstone, 1998; Warner, Weissman, Mufson, \& Wickramaratne, 1999), compared to the rate in the general population of $5 \%$ to $7 \%$ (Jellinek \& Snyder, 1998). Parental depression has also been linked to adolescent diagnoses of anxiety disorders and conduct disorder (Boyle \& Pickles, 1997; Wickramaratne \& Weissman, 1998).

Although research has focused on parents diagnosed with depression, other diagnoses are often considered more severe in terms of their impact on functioning (Oyserman et al., 2000). Thus, children of parents diagnosed with bipolar disorder or schizophrenia may be at even greater risk than are children of parents diagnosed with depression (Goodman \& Brumley, 1990). In fact, children whose parents have a bipolar disorder are 2.7 times more likely than other children to develop a mental disorder (Lapalme, Hodgins, \& LaRoche, 1997), are at risk for a diagnosis of attention-deficit/hyperactivity disorder (ADHD; Chang, Steiner, \& Ketter, 2000 ), and are also more likely to display a personality disorder (GrigoroiuServanescu et al., 1991). Chronicity of the mother's mental illness has also been found to significantly affect parenting, across diagnoses (Oyserman et al., 2000).

Although much of the research on adolescent children of mentally ill parents has examined risks for mental health problems or psychiatric diagnosis, less attention has focused on the functioning of these adolescents in academic, social, or behavioral domains. The available research does indicate that parental depression is significantly related to adolescent problems in school (Billings \& Moos, 1983; Hammen et al., 1987), lower gradepoint averages (Tannenbaum \& Forchand, 1994), problems with peer interactions (Billings \& Moos, 1983), reduced social competence (Thomas, Forehand, \& Neigh- bors, 1995), teen substance use (Su, Hoffmann, Gerstein, \& Johnson, 1997), and higher levels of adolescent internalizing and externalizing behavior problems (Thomas et al., 1995). Academic or cognitive difficulties, as well as emotionalbehavioral difficulties, have been reported for adolescent children of mothers with a bipolar disorder (Hammen et al., 1987), schizophrenia (Arbell et al., 1997), and other diagnoses (Rutter \& Quinton, 1987).

\section{CONTEXTUAL VARIABLES AS RISK FACTORS FOR ADOLESCENT OUTCOMES}

Individuals with serious mental illnesses ustaally experience concurrent difficulties with health, income levels, relationships, and other important life domains. Thus, mental illness is likely to be only a small part of the total risks that mothers and their children experience. Risks often include family disruptions and conflicts, singleparent status, social isolation, and financial and other stresses from living in impoverished conditions. These difficult life circumstances are often concomitant with chronic long-term mental illness and thus potentiate and exacerbate risk. However, to date, empirical evidence is insufficient to parse out and assess differential contributions of maternal psychiatric variables versus context (Oyserman et al., 2000). Further, many potentially significant contextual variables that could improve parenting and child outcomes have not been fully explored (e.g., children's separations from mother due to her mental illness; the satisfaction women gain from parenting).

\section{LIMITATIONS OF CURRENT RESEARCH KNOWLEDGE}

Few studies have cxamined psychosocial outcomes for teenage children of parents with bipolar disorders or schizophrenia. Investigators have not systematically compared adolescent outcomes across major categories of parental diagnosis. Evidence of the effects of parents' mental illness on their adolescent children has concentrated primarily on parental depression. Even in that research, there are significant limitations-involving mainly White, middle- class parents. Few investigators have included proportional representation of $\mathrm{mi}$ norities in their samples, which raises questions about the applicability of findings 10 more diverse groups. Furthermore, analyses have not simulaneously taken into account SES or race. In lact, many investigators do not specify their participations' race, ethnicity, or economic levels. These omissions are important because the literature on parenting has suggested that poverty can increase stress on parents, decreasing the quality of their parenting (Samaan, 1998), and that the relationship between minority status and parenting is complex (Oyserman, 2003). Studies are also limited in that most do not analyze for differences in the influence of maternal mental illness on girls versus boys, an important omission, given the established gender differences in trajectories for achievement and autonomy and the consequences of parental separation in adolescence. Finally, most researchers have concentrated on the effects of parental mental illness on children's mental health; much less research has examined its effects in academic, social, and behavioral domains. Risk of mental health problems may or may not relate to other important outcomes or 1o sucecssful engagement with school, social skills, peer relations, or behavior problems in the community (Luthar, Cicchetii, \& Becker, 2000). Some children who are at-risk may be functioning well in some domains but not in others, indicating the need to examine a broad constellation of positive and negative outcomes, strengths, and problems. Further, Radke-Yarrow and KlimesDougan $(2002)$ concluded that research on offspring of depressed parents has inappropriately examined problem outcomes as either present or absent and that assessments should take into account the form of the problem and any associated co-occurring disorders.

Our aim in the current research was to study diverse outcomes for teenage children of mothers with a serious mental illness and to identify predictors of outcomes from mothers' clinical history, as well as contextual features reflecting stress and resources. Previous gaps in the research were addressed by including a 
substantial number of minority youth in our sample, using measures that assessed outcomes of adolescence in all major life domains (academic, social, and behavioral, as well as mental health), and controlling for race/ethnicity, age, and gender as predictors of outcomes. To understand these diverse outcomes across multiple domains, we used a cluster analysis to identily similar groups.

\section{Method}

\section{Sample}

Participants were 166 teenage children and their mothers, participating in National Institutes of Mental Health-funded sludies of mothers with serious mental illness and their adoleseent children (see Mowbray, Oyserman, \& Bybee, 2000). In terms of maternal demographics, $60 \%$ were African American, 32\% non-Hispanic White, $6 \%$ Latina, and $2 \%$ other racial/ethnic groups. At the time of the youth interview, mothers were 40.5 years of age on average $(S D=5.8$, range $=26-$ 56 years); the median family income was $\$ 1,200$ per month, with $53 \%$ of the participants living below the poverty line; $23.6 \%$ of mothers were married; $44.2 \%$ were separated, divoreed, or widowed; and $32.1 \%$ were single (never married); $34.5 \%$ had less than a high school diploma, $21.8 \%$ had a high school diploma or GED, and $43.7 \%$ had some college education or more. Mothers' diagnoses were $23.3 \%$ schizophrenia/schizoaffective disorder, $52.3 \%$ depression, and $25.4 \%$ bipolat disorder. Youth were, on average, 15.0 years old $(S D=2.04) ; 87$ were boys, 79 girls. At lime of study recruitment, mothers had care responsibilities for an adolescent youth included in this study.

\section{Procedures}

Mothers were recruited from the public mental health system in two counties in southeast Michigan (including Detroit) and asked to participate in a longitudinal study about parenting and mental illness. ligible mothers had received public mental health services for a mental illness that lasted at leas1 1 year and interfered with one or more major areas of functioning. Originally, 485 women were identified as meeting study criteria: 46 could not be contacted or scheduled and 59 refused to be involved, producing a $78.4 \%$ participation rate. Mothers were interviewed three times over a 5 year period (approximately every 20 months), using a structured questionnaire. The retention rate, overall for the study, was $87.5 \%$. At the third interview for mothers with adolescent children, we requested permission to contact their children about participation in a study of adolescent transitions. The youth selected were mothers' youngest child in the age range of 11 to 17 years. The youngest child was chosen to increase the likelihood that children had not left school; in which case, interpreting the outcome measures across participants would have proved more problematic. Mothers were told that participation was voluntary and confidential and assured that we would not share any information about her situation with the youth, including her identification as a person with mental illness or recipient of mental health services. Written informed consent (guardian) and assent (youth) were obtained before the questionnaire administration. Youth were reimbursed for participating $(\$ 20$ at $\mathrm{T} 1$ and $\$ 25$ at $\mathrm{T} 2$ ). Interviewers were women ages 201045 ; all had prior experience with children, were university students, or had undergraduate degrees. They received extensive 3-day intervicwing training.

In total, 166 guardians (159 mothers and 7 other relatives) and youth consented and 39 refused $(81 \%)$. The structured interviews with the youth were approximately 2 hours in length and took place in the privacy of participants' homes. Interviewers provided a snack and a break midway through the questionnaire. Participating youth were recontacted, on average, about 40 weeks $(M=39.1$ weeks, $S D=13.64$, range $=21-88$ weeks) later for a follow-up (T2) questionnaire.

\section{Measures of Adolescent Outcomes}

According to the literature, youth's functioning may vary significantly across do- mains. Thus, to produce a comprehensive assessment and to determine the extent to which risk factors may predict differential outcomes, we selected measures from each major domain of adolescent functioning: academic, social, behavioral, and mental health. Details on the specific constructs, measures, and scale characteristics are provided in Table 1.

\section{Predictors of Adolescent Outcomes: Mother's Clinical Characteristics}

Diagnoses were determined at Wave 1, using the Depression, Mania, and Psychosis sections of the Diagnostic Interview Schedule (DIS; National Institute of Mental Health, 1980), Version III-R, modified for the Diagnostic and Statistical Manual of Mental Disorders-Fourth Edtion (DSM-IV; American Psychiatric Association, 1994) criteria. A psychologist with a PhD who was trained in the use of the DIS conducted training of lay interviewers. The structured nature of the protocol meant that intervicwers had few, if any, decisions to make in its administration. All intervicws were audiotaped, and a random $10 \%$ were reviewed for reliability. The clinical researcher reviewed completed intervicws (blind to the demographic characteristics of the participant) and assigned diagnoses manually using an algorithm based on the DIS protocol revised for the DSM-IV. Before being finalized, all diagnoses were rerevicwed by the clinical researcher and the interview coordinator; differences in diagnostic determinations were identified and discussed to reach a consensus determination for the final diagnosis.

Chronicity. Women reported their lifetime number of psychiatric hospitalizations $(M=4.24, S D=7.44, M d n=2$ ), which was then adjusted by the number of years since onset to minimize the effect of age, yielding an average number of hospitalizations per year mentally ill $(M=$ $0.32, S D=0.51, M d n=0$ ). This variable was log-transformed to minimize skew. The Drug Abuse Screening Test (DAST; Skinner, 1982), a measure of substance abuse history, providing a count of whether 
TABLE I

Descriptions of Adolescent Measures

\begin{tabular}{|c|c|c|c|c|}
\hline Domain & Construct & Scale & $\begin{array}{l}\text { \# items and } \\
\text { explanation }\end{array}$ & $\begin{array}{l}\text { Sample descriptive } \\
\text { statistics }\end{array}$ \\
\hline \multirow[t]{4}{*}{ Mental health } & Anxiety & $\begin{array}{l}\text { Revised Children's Manifest Anxiety } \\
\text { Scale (Cole, Hoffman, Tram, \& } \\
\text { Maxwell, 2000) }\end{array}$ & $\begin{array}{l}21 \text { items (omitted } 9 \text { items of } \\
\text { Social Desirability); count of } \\
\text { endorsed items }\end{array}$ & $\begin{array}{l}M=8.21, S D=6.09 \\
\quad \text { range }=0-28 \\
\alpha=.88\end{array}$ \\
\hline & $\begin{array}{l}\text { Depressive } \\
\text { symptoms }\end{array}$ & $\begin{array}{l}\text { Children's Depression Inventory } \\
\text { (Kovacs, 1992) }\end{array}$ & $\begin{array}{l}24 \text { items; } 0=\text { absence of symptom, } \\
\text { I = mild symptom, } 2 \text { = definite } \\
\text { symtom }\end{array}$ & $\begin{array}{l}M=8.25, S D=5.76 \\
\quad \text { range }=0-24 \\
\alpha=.88\end{array}$ \\
\hline & $\begin{array}{l}\text { Health } \\
\text { limitations }\end{array}$ & $\begin{array}{l}\text { Add Health In-School Questionnaire } \\
\text { (Natl. Longit. Study of Adoles- } \\
\text { cent Health, 1998) }\end{array}$ & $\begin{array}{l}6 \text { items; frequency health or emo- } \\
\text { tional problem caused difficulty, } \\
I=\text { never to } 5=\text { every day }\end{array}$ & $\begin{array}{l}M=0.33, S D=0.40 \\
\text { range }=0-2.17 \\
\alpha=.71\end{array}$ \\
\hline & Coping & $\begin{array}{l}\text { Negative Emotional Coping Scale } \\
\quad \text { (Eccles, 1995) }\end{array}$ & $\begin{array}{l}3 \text { items; } I=\text { never to } 5=\text { all the } \\
\text { time }\end{array}$ & $\begin{array}{l}M=1.96, S D=0.88 \\
\text { range }=1-5 \\
\alpha=.69\end{array}$ \\
\hline \multirow[t]{4}{*}{ Academic } & $\begin{array}{l}\text { School } \\
\text { competence }\end{array}$ & $\begin{array}{l}\text { Self-Perception Profile for Adoles- } \\
\text { cents (Harter, 1988) }\end{array}$ & $\begin{array}{l}7 \text { items; I = least competent to } 4= \\
\text { most competent }\end{array}$ & $\begin{array}{l}M=2.86, S D=0.67 \\
\quad \text { range }=1-4 \\
\alpha=.71\end{array}$ \\
\hline & $\begin{array}{l}\text { Grade Point } \\
\text { Average }^{\mathrm{a}}\end{array}$ & $\begin{array}{l}\text { From school records for semes- } \\
\text { ter preceding interview, core } \\
\text { and elective courses }\end{array}$ & $A=4$ to $F=0$ & $\begin{array}{l}M=2.17, S D=1.00 \\
\quad \text { range }=0-4\end{array}$ \\
\hline & $\begin{array}{l}\text { School } \\
\text { attachment }\end{array}$ & $\begin{array}{l}\text { School Bonding Scale (Cernkovich } \\
\text { \& Giordano, 1992) }\end{array}$ & $\begin{array}{l}4 \text { items; I = strongly disagree to } \\
5=\text { strongly agree }\end{array}$ & $\begin{array}{l}M=4.06, S D=0.64 \\
\quad \text { range }=2-5 \\
\alpha=.74\end{array}$ \\
\hline & $\begin{array}{l}\text { Academic } \\
\text { work }\end{array}$ & $\begin{array}{l}\text { Student Participation Questionnaire } \\
\quad \text { (Finn, Pannozzo, \& Voelkl, 1995) }\end{array}$ & 6 items; $1=$ never to 5 = always & $\begin{array}{l}M=3.38, S D=0.65 \\
\text { range }=1.67-5 \\
\alpha=.68\end{array}$ \\
\hline \multirow[t]{4}{*}{ Social } & $\begin{array}{l}\text { Peer } \\
\quad \text { involvement }\end{array}$ & $\begin{array}{l}\text { Peer Involvement Scale (Elliot, } \\
\text { Huizinga, \& Morse, 1985) }\end{array}$ & $\begin{array}{l}5 \text { items; support from and satisfac- } \\
\text { tion with friends, I = very little } \\
\text { to } 5=\text { a great deal }\end{array}$ & $\begin{array}{l}M=3.93, S D=0.77 \\
\quad \text { range }=1-5 \\
\alpha=.78\end{array}$ \\
\hline & $\begin{array}{l}\text { Social } \\
\quad \text { competence }\end{array}$ & $\begin{array}{l}\text { Self-Perception Profile for Adoles- } \\
\text { cents (Harter, 1988) }\end{array}$ & $\begin{array}{l}5 \text { items; I = least competent to } 4= \\
\text { most competent }\end{array}$ & $\begin{array}{l}M=3.00, S D=0.76 \\
\text { range }=1-4 \\
\alpha=.68\end{array}$ \\
\hline & $\begin{array}{l}\text { Perceived } \\
\text { physical } \\
\text { appearance }\end{array}$ & $\begin{array}{l}\text { Self-Perception Profile for Adoles- } \\
\text { cents (Harter, 1988) }\end{array}$ & $\begin{array}{l}5 \text { items; I = least attractive to } 4= \\
\text { most attractive }\end{array}$ & $\begin{array}{l}M=3.11, S D=0.81 \\
\quad \text { range }=1-4 \\
\alpha=.79\end{array}$ \\
\hline & $\begin{array}{l}\text { Peer } \\
\text { hassles }\end{array}$ & $\begin{array}{l}\text { Daily Hassles Microsystem Scale } \\
\quad \text { (Seidman et al., 1995) }\end{array}$ & 4 items; I = not at all to $4=a$ lot & $\begin{array}{l}M=1.45, S D=0.64 \\
\text { range }=1-4 \\
\alpha=.62\end{array}$ \\
\hline
\end{tabular}




\begin{tabular}{|c|c|c|c|c|}
\hline Domain & Construct & Scale & $\begin{array}{l}\text { \# items and } \\
\text { explanation }\end{array}$ & $\begin{array}{l}\text { Sample descriptive } \\
\text { statistics }\end{array}$ \\
\hline Social (cont'd) & $\begin{array}{l}\text { Exposure to } \\
\text { violence }^{c}\end{array}$ & $\begin{array}{l}\text { Violence witnessed or experi- } \\
\text { enced (Buke, Selner-O'Hagan, } \\
\text { Kindlon, \& Earls, 1996) }\end{array}$ & $\begin{array}{l}\text { I6 items; } 0=\text { never, } 1=\text { single expo- } \\
\text { sure, } 2 \text { = more than one expo- } \\
\text { sure, summed for a total score }\end{array}$ & $\begin{array}{l}M=9.5 I, S D=6.35 \\
\quad \text { range }=0-29\end{array}$ \\
\hline \multirow[t]{6}{*}{ Behavior } & $\begin{array}{l}\text { Peer deviant } \\
\text { values }\end{array}$ & $\begin{array}{l}\text { Perceived peer endorsement de- } \\
\text { viant behaviors (Eccles, 1995) }\end{array}$ & $\begin{array}{l}4 \text { items; I = very uncool to } 5=\text { very } \\
\text { cool }\end{array}$ & $\begin{array}{l}M=2.35, S D=1.11 \\
\quad \text { range }=1-5 \\
\alpha=.82\end{array}$ \\
\hline & Problem solving & $\begin{array}{l}\text { Adolescent Problems Inventory } \\
\text { (Freeman, Rosenthal, Donahue, } \\
\text { Schlundt, \& McFall, 1978) }\end{array}$ & $\begin{array}{l}9 \text { scenarios-social competency; } \\
5 \text {-pt rating scale: } 0=a \text { very in- } \\
\text { competent response to } 8=\text { a very } \\
\text { competent response }^{b}\end{array}$ & $\begin{array}{l}M=5.24, S D=1.28 \\
\text { range }=0.67-8.0 \\
\alpha=.69\end{array}$ \\
\hline & Internalizing & $\begin{array}{l}\text { Internalizing Problems subscale, } \\
\text { Youth Self-Report (Achenbach, } \\
\text { 1991) }\end{array}$ & $\begin{array}{l}3 \mathrm{I} \text { items; } 0=\text { not true, } \mathrm{I}=\text { some- } \\
\text { what or sometimes true, } 2=\text { very } \\
\text { true or often true }\end{array}$ & $\begin{array}{l}t \text { scored } \\
M=49.93, S D=11.61 \\
\text { range }=25-79\end{array}$ \\
\hline & Externalizing & $\begin{array}{l}\text { Externalizing Problems subscale, } \\
\text { Youh Self-Report (Achenbach, } \\
\text { 1991) }\end{array}$ & $\begin{array}{l}3 \mathrm{I} \text { items; } 0=\text { not true, } \mathrm{I}=\text { some- } \\
\text { what or sometimes true, } 2=\text { very } \\
\text { true or often true }\end{array}$ & $\begin{array}{l}t \text { scored } \\
M=48.82, S D=10.40 \\
\text { range }=26-86\end{array}$ \\
\hline & Police contacts ${ }^{c}$ & $\begin{array}{l}\text { Police Contact (Elliott et al., } \\
\text { 1985) }\end{array}$ & $\begin{array}{l}4 \text { items; questioned or arrested by } \\
\text { police or gone to court in the } \\
\text { last } 12 \text { months, } 0=\text { no, } I=\text { yes }^{d}\end{array}$ & $\begin{array}{l}M=.56, S D=1.00 \\
\text { range }=1-4\end{array}$ \\
\hline & Delinquency & $\begin{array}{l}\text { Add Health In-Home Quest. (Natl. } \\
\text { Longitud. St. Adol. Health, } \\
\text { 1998) }\end{array}$ & $\begin{array}{l}\text { I4 items; } 0=\text { never to } 3=\text { five or } \\
\text { more times }\end{array}$ & $\begin{array}{l}M=0.23, S D=0.31 \\
\quad \text { range }=0-2.29 \\
\alpha=.85\end{array}$ \\
\hline
\end{tabular}

${ }^{a}$ Grade Point Average was based on 4 or more classes (all classes for which we had grades—core classes plus electives), with the exception of the following: I was based on 2 classes, I was based on 3 classes, and 12 were based on statistical estimation techniques. bA competent response was defined as one that effectively resolves the problem situation and makes it less likely that the respondent will have more problems of this type in the future; for coding agreements across scenarios, Kappa $=0.56-0.88$. Internal consistency reliability statistics are not provided for count measures. As indicators, rather than items which are manifestations of an underlying hypothetical construct, they do not meet the criteria of classical test theory and therefore are not appropriate for internal consistency statistics (Streiner, 2003). ${ }^{\mathrm{d}}$ Typical of count measures, this variable was positively skewed and was log-transformed to better meet the distributional assumptions of the analysis.

or not certain behaviors were associated with ever using substances, was adapted 10 be more appropriate for women $(M=$ $5.12 ; S D=4.8 ; \alpha=.94)$.

Number of Years Child Separated From Mother. A Life History Calendar was used to help women recall separations from each of their children due to custody loss or other reasons. The total number of years with a 3-month or longer separation from the mother (before age 19) was computed for each child $(M=1.58, S D=3.17$, range $=(0-16)$.

\section{Predictors: Contextual Characteristics}

Demographic Information. Mothers reported their age, race, education, and living arrangements. The Maternal Wave 3 intervicw included a checklist of income sources to determine total monthly income $(M=\$ 1,312, S D=\$ 715, M d n=$ $\$ 1,195$, range $=\$ 0-\$ 3,900)$. Household adjusted family income was calculated as a percentage of the poverty level for the houschold size (U.S. Census Bureau, $1996 ; M=101.72 \%, S D=54.0 \%, M d n=$
$88.7 \%$ ). Meaning of Motherhood (Oyserman, Bybee, Mowbray, \& Kahng, in press), a measure of parenting attitude, was obtained with 6 open-ended questions, coded to consensus by two trained raters on variables such as negativity, restrictiveness, self-efficacy, nurturance, and feeling valued (correlations between coders on a random sample of 50 cases, Spearman tho, ranged from .51 to .86). Coded responses were factor-analyzed, and the largest factor-positive and efficacious parenting - was used in this analysis $(M=$ $-0.066, S D=1.015$, range $=-2.43-2.81)$. 
Stressful social life events in the past year were assessed with a subset of 6 items from the Bricf Life Events Questionnaire (Brugha \& Cragg, 1990 ; e.g., break-up of relationships, conflict with others, deaths/ serious illness of family or friends; $M=$ $1.57, S D=1.38$, range $=0-5)$. Mothers' total positive social support (Arizona Social Support Interview Schedule; Barrera, 1986) was a count of all those listed as available to provide any type of positive social support $(M=6.65, S D$ 3.55, range $=$ $0-21$ ). Paternal involvement was assessed from youth with one item from the Social Support Microsystems Scale (Seidman et al. 1995), a dichotomous question of "in life" versus "not in life" (22.6\% yes).

\section{Analysis Plan}

The cluster analysis used traditional hierarchical agglomerative and $k$-means clustering methods because our sample size was not optimal for maximum-likelihood modeling methods such as latent profile (Bartholomew \& Knott, 1999) or latent class cluster analysis (Vermunt \& Magid.son, 2002). We also wanted to avoid imposing unrealistic covariance constraints such as within-class independence, which latent class-based methods often require in order to achieve convergence (Vermunt \& Magidson, 2002). Cluster analysis requires the selection of a limited number of variables to be used in the clustcring statistical procedure. From Youth Wave $]$ data, we selected two measures to exemplify outcomes from each of the four major domains of functioning for adolescents: Mental Health (anxiety and depression), Academic (school competence and school record grade point average [GPA]), Social (peer involvement and social competence), and Behavior (peer deviant values and adolescent problem solving). Within each domain, the measures used as the clustering variables were (a) selected from outside sources (school records, interview rating) and were therefore more likely to be valid representations of the variable, (b) well-respected and highly reliable measures, and (c) relatively independent (except for anxicty and depression, which were both selected because it is possible to have one without the other; see Grigoroiu-Servanescu et al., 1991). In contrast, measures external to the cluster solution (used to further describe the clusters) were related to but not central measures of the variables or represented specific but limited components of the variables (e.g., health limitations and coping for mental health; self-reports of school attachment and academic work for academics; perceptions of physical appearance, peer hassles, and exposure to violence for social outcomes; internalizing, externalizing, police contacts, and delinquency for behavior problems).

Before conducting the cluster analysis, we standardized all variables to reduce differential weighting due to scaling differences. We used a two-stage method for the cluster analysis. The first stage was a hierarchical agglomerative cluster analysis on squared Euclidean distances among the 141 cases with complete data on all cluster-defining variables. Ward's method was used because it minimizes withincluster variation and cends to produce clusters of relatively similar size (Blashfield \& Aldenderfer, 1988). Examination of fusion coefficients suggested an optimal solution consisting of five clusters. We followed the agglomerative procedure by a $K$-means iterative cluster analysis, based on the mean centroids from the hierarchical method. This second, iterative step allowed cases that had migrated away from cluster centroids during the agglomerative process to be reassigned, resulting in clusters with the smallest possible within-cluster variance. The $k$-means procedure also assigned to clusters 24 cases (14.4\%) with missing values on one or two of the eight clustering variables based on existing data points. Onecase was dropped because it had valid data on only two clustering variables, resulting in $N=165$. We assessed the technical adequacy of the cluster solution using measures of withincluster dispersion and between-cluster distances (Sneath \& Sokal, 1973). For all clusters, the smallest between-cluster distance was greater than the within-cluster dispersion. Although quite small, the fifth cluster was retained because it was far removed from the nearest cluster and an alternate four-cluster solution dramatically increased within-cluster dispersion.
Following the cluster analysis, to more fully describe cach cluster, we examined cluster differences on other youth variables not included in the cluster solution (i.e., variables external to the cluster analysis). To test differences between clusters on the clustering variables and on the variables external to the cluster analysis, we used MANOVA, followed by univariate ANOVAs and paired comparison tests 10 assess differences between indjvidual clusters. Following recommendations of Hancock and Klockars (1996) and Wilcox (1987), we examined paired comparisons for all dependent variables, regardless of the significance of the overall univariate $F$ or chi-square. To maintain alpha for each dependent variable at $p<$ .05, we used Games-Howell tests (Games, Keselman, \& Rogan, 1981) or modilied Bonferroni adjustments (Jaccard \& Wan, 1996) for the paired comparisons. Given the cluster conliguration described in the next section, power exceeded 85 to detect, at $p<.05$, overall cluster differences that were at least "medium-sized," according 10 Cohen's (1988) hresholds $(w=.3$ for categorical and $d=.5$ for continuous variables). For most of the paired comparison tests, power was sufficient to detect large effects $(w=.50$ or $d=.80)$ at Bonferroni-adjusted $p<.05$, ranging from .70 to .88 for all comparisons except those involving the smallest cluster, where power dropped below .5().

To test possible predictors of eluster membership, we used multinomial logistic regression, an extension of logistic regression for nominal dependent variables with more than two caltegorics (Long, 1997). We performed the analysis in a hierarchical manner, entering predictors in ordered blocks to facilitate testing the significance of influences of a more transitory nature (c.g., disruptive life events), controlling for the effects of immutable characteristics (demographics, matemal psychiatric history).

\section{RESULTS}

\section{Cluster Derivation}

Table 2 presents the cluster means for the eight variables used to define the cluster 
TABLE 2

Variables Used to Define Clusters, by Cluster

\begin{tabular}{|c|c|c|c|c|c|c|c|}
\hline \multirow[b]{2}{*}{ Dependent variable } & \multirow[b]{2}{*}{$\begin{array}{c}\text { Pseudo } F \\
(4,160)\end{array}$} & \multicolumn{6}{|c|}{ Raw and (Standardized) Means } \\
\hline & & $\begin{array}{c}I \\
(n=50)\end{array}$ & $\begin{array}{c}2 \\
(n=25)\end{array}$ & $\begin{array}{c}3 \\
(n=37)\end{array}$ & $\begin{array}{c}4 \\
(n=45)\end{array}$ & $\begin{array}{c}5 \\
(n=8)\end{array}$ & $\begin{array}{c}\text { Total } \\
N=165\end{array}$ \\
\hline Anxiety & $31.43 *$ & $\begin{array}{r}5.24 \mathrm{a} \\
(-0.49)\end{array}$ & $\begin{array}{l}17.47 \mathrm{~b} \\
(1.52)\end{array}$ & $\begin{array}{r}7.46 \mathrm{a} \\
(-0.12)\end{array}$ & $\begin{array}{r}6.86 \mathrm{a} \\
(-0.22)\end{array}$ & $\begin{array}{r}8.55_{a} \\
(0.06)\end{array}$ & 8.20 \\
\hline Depression & $67.93^{*}$ & $\begin{array}{r}4.32 \mathrm{a} \\
(-0.68)\end{array}$ & $\begin{array}{l}18.36 \mathrm{~b} \\
(1.75)\end{array}$ & $\begin{array}{r}7.2 I_{c} \\
(-0.18)\end{array}$ & $\begin{array}{r}7.43 c \\
(-0.14)\end{array}$ & $\begin{array}{l}10.50_{\mathrm{ac}} \\
(0.39)\end{array}$ & 8.25 \\
\hline School competence & $17.24^{*}$ & $\begin{array}{r}3.4 \mathrm{I}_{\mathrm{a}} \\
(0.83)\end{array}$ & $\begin{array}{r}2.47 \mathrm{~b} \\
(-0.58)\end{array}$ & $\begin{array}{r}2.67 \mathrm{~b} \\
(-0.28)\end{array}$ & $\begin{array}{r}2.66_{b} \\
(-0.29)\end{array}$ & $\begin{array}{c}2.65_{\mathrm{ab}} \\
(-0.3 \mathrm{I})\end{array}$ & 2.86 \\
\hline Grade Point Average & $|2.3| *$ & $\begin{array}{r}2.73_{\mathrm{a}} \\
(0.57)\end{array}$ & $\begin{array}{r}1.5 \mathrm{I}_{\mathrm{b}} \\
(-0.59)\end{array}$ & $\begin{array}{r}2.37{ }_{a} \\
(0.24)\end{array}$ & $\begin{array}{r}1.56_{b} \\
(-0.55)\end{array}$ & $\begin{array}{l}2.18_{\mathrm{ab}} \\
(0.05)\end{array}$ & 2.13 \\
\hline Peer involvement & $30.27 *$ & $\begin{array}{l}4.13_{\mathrm{a}} \\
(0.27)\end{array}$ & $\begin{array}{l}4.08_{\mathrm{ab}} \\
(0.19)\end{array}$ & $\begin{array}{r}3.67 b \\
(-0.34)\end{array}$ & $\begin{array}{r}4.20 \mathrm{a} \\
(0.36)\end{array}$ & $\begin{array}{r}1.90 c \\
(-2.64)\end{array}$ & 3.93 \\
\hline Social competence & $30.56^{*}$ & $\begin{array}{r}3.60_{a} \\
(0.78)\end{array}$ & $\begin{array}{r}2.53_{\mathrm{b}} \\
(-0.62)\end{array}$ & $\begin{array}{r}2.39 \mathrm{~b} \\
(-0.81)\end{array}$ & $\begin{array}{r}3.23_{\mathrm{c}} \\
(0.30)\end{array}$ & $\begin{array}{r}2.45_{\mathrm{b}} \\
(-0.73)\end{array}$ & 3.01 \\
\hline Peer deviant values & $28.77^{*}$ & $\begin{array}{r}1.80 \mathrm{a} \\
(-0.50)\end{array}$ & $\begin{array}{l}2.96_{\mathrm{b}} \\
(0.54)\end{array}$ & $\begin{array}{r}1.56 \mathrm{a} \\
(-0.72)\end{array}$ & $\begin{array}{c}3.08_{\mathrm{b}} \\
(0.65)\end{array}$ & $\begin{array}{r}3.66_{\mathrm{b}} \\
(1.17)\end{array}$ & 2.35 \\
\hline Problem solving & $21.35^{*}$ & $\begin{array}{r}5.92{ }_{a} \\
(0.53)\end{array}$ & $\begin{array}{r}4.3 \mathrm{I}_{\mathrm{b}} \\
(-0.72)\end{array}$ & $\begin{array}{r}5.94 \mathrm{a} \\
(0.55)\end{array}$ & $\begin{array}{r}4.40 \mathrm{a} \\
(-0.66)\end{array}$ & $\begin{array}{l}5.28_{\mathrm{ab}} \\
(0.03)\end{array}$ & 5.24 \\
\hline
\end{tabular}

Note. For each variable, raw scores are in the first row, and standardized (z scores) are below. $F$ is maximized by the clustering procedure. $a, b$ Means that do not share the same subscript letter are significantly different at $p<.05$, using Games-Howell paired comparison tests. $* p<.001$.

solution, along with ANOVA and paired comparison results. As an example of the latter, means on depression for each clusker plus the total sample are displayed in the second row (raw scores on top; standardized scores in parentheses, underneath). The mean for Cluster 1 (4.32) is identificd by superscript "a," indicating that this cluster is significantly different on depression from Cluster 2 (superscript "b") and from Clusters 3 and 4 (superscript "c"), although not significantly different from Cluster 5 (superscript "ac"); Cluster 2 is also significantly different from Clusters 3, 4, and 5, because none of these shares a superscript " $b$ ". Examination of cluster differences on these defining variables led to the assignment of labels: (a) Socially and Academically ('ompetent; (b) Anxious and Depressed; (c) Average, Adult-Oriented Youths; (d) Delinquent/Peer-Oriented; and (e) Isolated Non-Conformists (see Figure 1). On demographic variables (Table 3), clustcrs differed significantly on age and sex, but not on race. The paired comparisons on age revealed that youths in the Competent and Average clusters were significantly younger than those in the Delinquent/ Peer-Oriented cluster. In terms of gender differences, the Delinquent cluster had significantly fewer girls than the Anxious/ Depressed or the Average clusters.

Table 4 presents cluster comparisons on mental health, academic, social, and behavior variables that were external to the cluster analysis. Age and sex were covariates in the multivariate and univariate ANCOVAs testing overall differences, as well as in paired comparisons among individual clusters (in order to avoid reporting spurious cluster differences that could be attributed to demographic differences). Means in Table 4 are age- and sexadjusted. MANCOVA results, by domain, were all significant, as were most of the univariate ANCOVA results in each domain.

\section{Cluster Descriptions}

Cluster 1: Socially and Academically Competent. This was the largest cluster with $n=50(30.1 \%)$. It had the lowest mean anxicty score, the lowest depression score, the highest school competence score, and the highest GPA. Average peer involvement score was high, and members also scored significantly higher than all other clusters on social competence, lower on peer deviant values than all clusters but one, and higher than all but one on problem solving. Cluster I showed the best adjustment and fewest problems across multiple domains (see Table 4). Thus, in the mental health domain, these adolescents had few health limitations and low scores for negative emotional coping. They were also significantly better in the

212 JOURNAL OF EMOTIONAL AND BEHAVIORAL DISORDERS, WINTER 2004, VOL, I2, NO. 4 


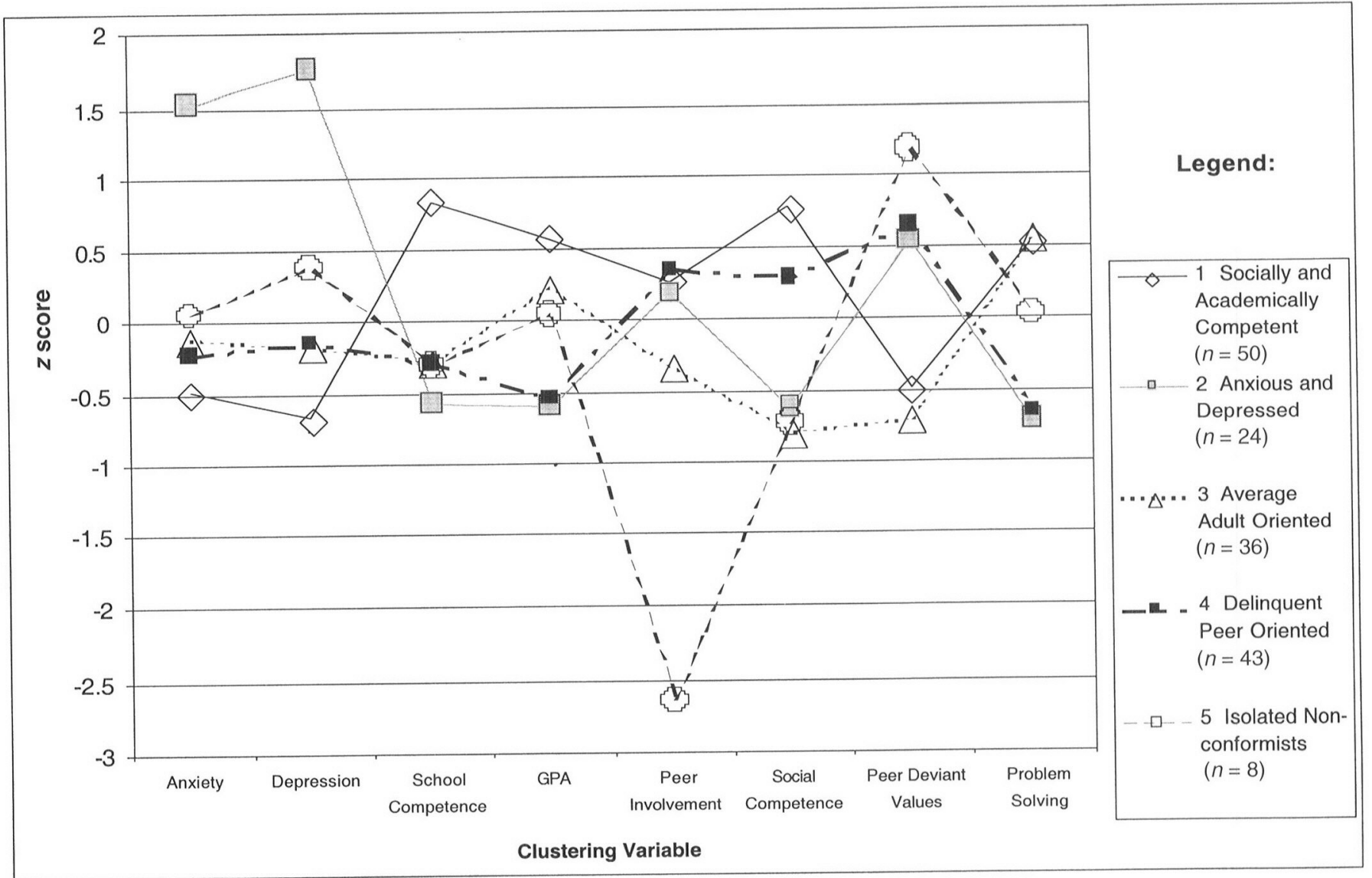

FIGURE I. Cluster profiles on defining variables.

academic domain, with the highest mean level of school attachment and positive self-report of academic work. In the social domain, this cluster differed from others in having the highest scores on perceived physical appearance. They were less bothered by peer hassles and experienced less exposure to violence than some other clusters. In the behavior domain, they had the lowest scores on internalizing and externalizing behaviors and low scores on police contacts and delinquency.

Cluster 2: Anxious and Depressed. The second cluster $(n=25,15.1 \%)$ scored significantly higher than all other clusters on the anxiety and depression measures (see Table 2). They had the lowest selfassessed school competence, and their GPA was low. Their peer involvement score was higher than one cluster, but the perceived social competence score was significantly lower than another cluster. They also had significantly higher peer deviant values and significantly lower problem solving, relative to the Competent and Average clusters. The Anxious/ Depressed cluster also differed significantly from other clusters in attitudes and behaviors in multiple domains (see Table 4). On mental health variables, they reported the highest jevels of health limitations and negative emotional coping. In the academic area, their reported school attachment was lowest and they were significantly less positive about their academic work than the Competent or Average clusters. In the social domain, they rated themselves low in perceived physical appearance and were significantly more bothered by peer hassles than any of the other clusters; they reported significantly more exposure to violence than any of the other clusters but one. Finally, in the behavioral area, they had the highest scores on internalizing and externalizing problems, were significantly higher on delinquency than two of the other clusters, but did not differ from other clusters on police contact.

Cluster 3: Average, Adult-Oriented Youths. This cluster's $(n=37,22.3 \%)$ scores on most variables were midrange, significantly higher than some clusters and lower than others (see Table 2). They were signilicantly lower on mental health problem variables than the Anxious/ Depressed cluster but higher on depression than the Competent cluster. Their self-perceived school competence was significantly lower than the Competent cluster, but their school GPA was significantly higher than the Anxious/Depressed or Delinquent/Peer-Oriented clusters. Peer involvement and social competence were significantly lower than the Competent or Delinquent/Peer-Oriented clusters, but peer involvement was higher than that of the Isolated Non-Conformist cluster. In the behavioral domain, they had the lowest score on peer deviant values and the 
TABLE 3

Background Characteristics by Cluster

\begin{tabular}{|c|c|c|c|c|c|c|}
\hline Characteristic & $\begin{array}{l}\text { Comparison } \\
\text { statistic }\end{array}$ & $\begin{array}{l}\text { Socially and } \\
\text { academically } \\
\text { competent } \\
(n=50)\end{array}$ & $\begin{array}{l}\text { Anxious } \\
\text { and } \\
\text { depressed } \\
(n=25)\end{array}$ & $\begin{array}{l}\text { Average } \\
\text { adult } \\
\text { oriented } \\
(n=37)\end{array}$ & $\begin{array}{l}\text { Delinquent } \\
\text { peer } \\
\text { oriented } \\
(n=45)\end{array}$ & $\begin{array}{l}\text { Isolated } \\
\text { non- } \\
\text { conformist } \\
(n=8)\end{array}$ \\
\hline Youth age at interview ${ }^{\prime}$ & $5.280 *$ & $14.306 \mathrm{a}$ & $15.422_{\mathrm{ab}}$ & $14.506_{a}$ & $15.839_{b}$ & $16.153_{\mathrm{ab}}$ \\
\hline $\begin{array}{l}\text { Household ratio of poverty } \\
\text { threshold' }\end{array}$ & 0.295 & 0.908 & 0.841 & 0.973 & 0.904 & 0.859 \\
\hline Youth race (\% African-American) ${ }^{2}$ & 6.035 & $67.3 \%$ & $48.0 \%$ & $68.6 \%$ & $56.8 \%$ & $87.5 \%$ \\
\hline Youth sex (\% female respondents $)^{2}$ & $13.784^{*}$ & $49.0 \% \%_{a b}$ & $64.0 \%{ }_{a}$ & $60.0 \%{ }_{a}$ & $27.3 \%_{b}$ & $25.0 \%_{a b}$ \\
\hline $\begin{array}{l}\text { Child employment (\% worked in } \\
\text { last year) })^{2}\end{array}$ & $18.579 * *$ & $32.7 \%_{a}$ & $48.0 \%{ }_{\mathrm{ab}}$ & $31.4 \%{ }_{a}$ & $72.1 \%$ & $37.5 \%$ ab \\
\hline $\begin{array}{l}\text { Live with mother ( } \% \text { more than } \\
\text { half the year) })^{2}\end{array}$ & 4.453 & $81.6 \%$ & $83.3 \%$ & $71.4 \%$ & $66.7 \%$ & $62.5 \%$ \\
\hline
\end{tabular}

'Cluster means and $F$ reported for continuous variables. ${ }^{2}$ Cluster percentages and chi-square reported for dichotomous variables. $a, b, c$ Cell entries that do not share the same superscript letter are significantly different according to modified Bonferroni tests at $p<.05$, adjusted for multiple comparisons within each dependent variable.

$* p<.01 . * * p<.001$.

TABLE 4

Cluster Means on Variables External to the Cluster Solution, by Dependent Variable Domain

\begin{tabular}{|c|c|c|c|c|c|c|}
\hline Variable domain & $\boldsymbol{F}$ & $\begin{array}{l}\text { Socially and } \\
\text { academically } \\
\text { competent } \\
(n=50)\end{array}$ & $\begin{array}{l}\text { Anxious } \\
\text { and } \\
\text { depressed } \\
(n=25)\end{array}$ & $\begin{array}{l}\text { Average } \\
\text { adult } \\
\text { oriented } \\
(n=37)\end{array}$ & $\begin{array}{l}\text { Delinquent } \\
\text { peer } \\
\text { oriented } \\
(n=45)\end{array}$ & $\begin{array}{l}\text { Isolated } \\
\text { non- } \\
\text { conformist } \\
(n=8)\end{array}$ \\
\hline \multicolumn{7}{|l|}{ Mental health Mult. $F(8,308)=4.174 * *$} \\
\hline Health limitations & $3.989 *$ & $0.27 \mathrm{I}_{\mathrm{a}}$ & $0.608_{b}$ & $0.248_{a}$ & $0.353_{\mathrm{ab}}$ & $0.190_{\mathrm{ab}}$ \\
\hline Negative emotional coping & $6.78 I^{*} *$ & $1.644_{\mathrm{a}}^{\mathrm{a}}$ & $2.704_{b}$ & $1.819_{\mathrm{a}}^{\mathrm{a}}$ & $1.969_{\mathrm{a}}^{\mathrm{ab}}$ & $2.026_{\mathrm{ab}}$ \\
\hline \multicolumn{7}{|l|}{ Academic Mult. $F(8,306)=6.452^{* *}$} \\
\hline School attachment & $8.766 * *$ & $4.410_{\mathrm{a}}$ & $3.532_{b}$ & $4.090_{\mathrm{ac}}$ & $4.01 I_{c}$ & $3.928_{a b c}$ \\
\hline Academic work & $7.101 * *$ & $3.62 \mathrm{I}_{\mathrm{a}}^{\mathrm{a}}$ & $3.075_{b}^{b}$ & $3.662_{a}$ & $3.174_{b}^{c}$ & $2.838_{b}$ \\
\hline \multicolumn{7}{|l|}{ Social Mult. $F(12,450)=6.276 * *$} \\
\hline Perceived physical appearance & $7.495 * *$ & $3.495 \mathrm{a}$ & $2.537_{b}$ & $2.923_{b}$ & $3.253_{b}$ & $3.032_{\mathrm{ab}}$ \\
\hline Peer hassles & $5.613^{* *}$ & $1.299_{\mathrm{a}}^{\mathrm{a}}$ & $1.917_{b}^{b}$ & $1.298_{\mathrm{a}}^{\circ}$ & $1.498_{a}$ & $1.327_{\mathrm{ab}}^{\mathrm{ao}}$ \\
\hline Exposure to violence & $8.498 * *$ & $7.148_{\mathrm{a}}^{\mathrm{a}}$ & $13.935_{b}^{b}$ & $7.510_{\mathrm{a}}^{\mathrm{a}}$ & $11.890_{b}^{a}$ & $7.807_{\mathrm{ab}}^{\mathrm{a}}$ \\
\hline \multicolumn{7}{|l|}{ Behavior Mult. $F(16,616)=3.535^{* *}$} \\
\hline Internalizing problems & $8.561 * *$ & $43.777_{a}$ & $57.534_{b}$ & $49.852_{c}$ & $48.155_{\mathrm{ac}}$ & $49.743_{\mathrm{abc}}$ \\
\hline Externalizing problems & $4.74 I^{*}$ & $45.567_{a}^{a}$ & $56.940_{b}$ & $48.597_{\mathrm{a}}^{\mathrm{c}}$ & $52.552_{b}^{a c}$ & $48.819_{a b}$ \\
\hline Police contact & $3.198 *$ & $0.315_{a}^{a}$ & $0.769^{\circ}$ & $0.369^{a}$ & $0.968_{b}$ & $-0.024_{a}^{a b}$ \\
\hline Delinquency & $5.317 * *$ & $0.118_{\mathrm{a}}^{a}$ & $0.402_{b}^{a}$ & $0.162_{a}^{a}$ & $0.343_{b}^{\circ}$ & $0.244_{\mathrm{ab}}^{\mathrm{a}}$ \\
\hline
\end{tabular}

Note. For each domain, values reflect an overall MANCOVA plus ANCOVAs for each dependent variable. Means are adjusted for the covariates, age, and gender.

a,b,c Means that do not share the same subscript letter are significantly different according to modified Bonferroni tests at $p<.05$, adjusted for multiple comparison within each dependent variable.

$*_{p}<.01 . * *_{p}<.001$. 
highest score on problem solving-both measures reflect endorsing values and behaviors congruent with adult expectations. For employment, post-hoc comparisons indicated that youth in this cluster were significantly less likely to be working than those in the Delinguent/PeerOriented cluster. Average Adult-Oriented Youth (see Table 4) differed primarily from the Anxious/Depressed cluster in the mental health and academic domains, having significantly fewer health limitations, less negative emotional coping, and stronger school attachment; scores on academic work were significantly higher than any cluster except the Competent group. In the social domain, they scored significantly lower than the Competent cluster on perceived physical appearance. The Average Adult-Oriented Youths cluster was bothered less by peer hassles than the Anxious/ Depressed cluster and reported lower exposure to violence than that cluster or the Delinquent/ Peer-Oriented cluster. For behavioral variables, the internalizing scores for the Average cluster were significantly lower than Anxious/ Depressed but significantly higher than the Competent cluster. Members of the Average, Adult-Oriented Youths cluster reported less delinquency than the Delinquent/Peer-Oriented or Anxious/ Depressed clusters.

Cluster 4: Delinquent/Peer-Oriented. Cluster 4 was the second largest cluster $(n=45,27.1 \%)$ and about average on the mental health variables. School competence was significantly lower than the Competent cluster, and GPA was significantly lower than the Competent and $\mathrm{Av}$ erage clusters. Cluster members scored highest on peer involvement and high on social competence. Peer deviant values were significantly higher, and problem solving was significantly lower than in the Competent and Average clusters (see Table 2). On the external variables (sec Table 4), the Delinquent/Peer-Oriented cluster showed very high scores in the social and behavioral problems domains. On mental health variables, they had lower negative emotional coping. They showed less school attachment than the Competent cluster (but more than the Anxious/
Depressed) and reported less orientation to academic work than the Competent or Average clusters. In the social domain, there were differences with the Anxious/ Depressed cluster (higher perceived physical appearance and fewer peer hassles). There were also differences with the Competent and Average Youth clusters in having more exposure to violence. Finally, differences with other clusters were also found in the behavioral domain, with lower scores on internalizing problems, higher externalizing, more police contacts, and more delinquency.

Cluster 5: Isolated Non-Conformists. Cluster 5, was the smallest cluster ( $n=8$, $4.8 \%$ ). This cluster was generally characterized by average scorcs, except for the social domain and peer deviant values (see Table 2). Thus, mental health problems were about at the overall mean and only significantly different from the Anxious/ Depressed cluster. The school competence and GPA scores were midrange and not significantly different from any other cluster. However, cluster members had the lowest peer involvement and social competence. They also had the highest peer deviant values but were midrange and did not differ from any other clusters on problem solving. The scores on the extemal cluster variables for this cluster indicated that while these students reported that their peers held deviant values, their own behavior was not especially deviant or delinquent. In fact, in the mental health and social domains, this cluster showed no significant differences from other clusters. In the academic domain, members of this cluster were significantly lower on academic work than the Competent or Average clusters; in the behavior domain, they reported significantly less police contact than the Delinquent/PeerOriented cluster (see Table 4).

\section{Predictors of Cluster Membership}

The results of the hierarchical multinomial logistic regression analysis, examining potential predictors of cluster membership, are presented in Table 5. For this analysis, sample size was $N=155$, due to missing data on one or more variables. To allow us to test the significance of more changeable influences while controlling for the effects of immutable characteristics (e.g., child demographies, maternal psychiatric history), we entered the predictors in ordered blocks: Block 1 conlained child demographics, Block 2 matemal psychiatric history variables, Block 3 social context variables, and Block 4 maternal conceptualizations of the meaning of motherhood in her life. Because order of entry had little effect on the coefficients, only the final results (Block 4) are presented in Table 5. The odds ratios in the lable indicate the effect of a unit difference in each predictor on the odds that a youth would be in cach indicated cluster, rather than in the Socially and Academically Competent cluster, which served as the reference group for all comparisons. The linal row of Table 5 contains HosmerLemeshow goodness-of-fit chi-square tests for binomial logistic regressions comparing each eluster with the Academically Competent group. None of these tests is significant, and diagnostic graphs identified no problematic influential or illfitting observations, suggesting that the overall model is an adequate fit to the data, although it should be noted that power to reject the null hypothesis of model fit is limited given the current sample size (Hosmer \& Lemeshow, 20)(0)).

Block 1 consisted of child demographics as control variables. Child gender was a significant predictor of cluster membership: boys were nearly 4 limes as likely to be in the Delincuent/PeerOriented as the Academically Competent cluster. Child age wats also a signilicant predictor in this block; older children were significantly more likely to be in the Anxious/Depressed,

\section{Delinquent/Peer-Oriented, or Isolated Non-Conformist clusters.}

In Block 2, we examined the eflects of variables reflecting maternal psychiatric history, controlling for child gender and age. Depression diagnoses were contrasted with all others, because initial analyses revealed no differences between 
TABLE 5

Hierarchical Multinomial Logistic Regression on Cluster Membership From Maternal Predictors

Odds ratios relative to academically competent cluster

Predictors at final block

Anxious \& Average

depressed adult-oriented

$\begin{array}{ccc}\begin{array}{c}\text { Delinquent } \\ \text { peer-oriented }\end{array} & \begin{array}{c}\text { Isolated } \\ \text { non-conformist }\end{array} & \begin{array}{c}L R \chi^{2} \text { I } \\ (\mathrm{d} f=4)\end{array}\end{array}$

Block I - Child demographics

Child gender ( $\mathrm{I}=$ boy)

Child age

$\begin{array}{lllll}0.561 & 0.811 & 3.905^{*} & 1.210 & 10.973^{*} \\ 1.410^{*} & 0.975 & 1.567^{* *} & 2.630^{* *} & 21.526^{* * *} \\ & & & & \\ 1.300 & 1.450 & 2.920 & 0.834 & 3.806 \\ 1.060 & 1.100 & 1.243^{* * *} & 1.200 & 14.226 * * \\ 0.686 & 0.977 & 1.069 & 0.894 & 6.779 \\ 0.978 & 1.070 & 1.062 & 0.864 & 3.096 \\ & & & & \\ 0.586 * & 0.783 & 0.699 & 0.279 & 9.457 \\ 0.992 & 1.020 & 1.080 & 0.438^{*} & 12.189^{*} \\ 0.425 & 0.217^{*} & 0.138^{* *} & 0.101 & 10.316^{*} \\ & & & & \\ 1.210 & 0.898 & 0.536^{*} & 1.270 & 7.439 \\ 3.687 & 2.640 & 0.150 & 9.340^{* *} & 19.002^{* *} \\ 4.160 & 6.730 & 9.590 & 0.000 & \end{array}$

Block 2 - Maternal psychiatric history

Maternal diagnosis-affective

Maternal substance abuse history

Year with maternal separation

Maternal hospitalizations (lifetime)

Block 3 - Social context

Social life events

Social support available

Father in child's life

Block 4 - Meaning of motherhood

Positive meaning of motherhoood

Intercept

6.730

9.590

0.000

Note. $N=$ 155. All odds ratios involve comparisons with the Academically Competent cluster. Significance of each odds ratio is based on the Wald statistic (value not shown). The logistic regression was done hierarchically, by the numbered blocks; the tabled odds ratios are taken from the final model.

IOverall likelihood ratio chi-square for each predictor variable.

${ }^{2}$ Goodness-of-fit tests are for binomial regressions comparing each to the Academically Competent cluster.

$* p<.05$. ** $p<.01$. *** $p<.001$.

schizophrenia/schizoaffective and bipolar diagnoses. Only maternal substance abuse history was a significant overall predictor of cluster membership, and only one of the comparisons with the Competent cluster wals signilicant: Youth whose mothers had more problematic substance abuse histories were more likely to be in the Delinquent/Peer-Oriented cluster, compared to the Academically Competent. None of the other maternal psychiatric variables-diagnosis, childhood separalions from the mother, lifetime maternal psychiatric hospitalizations-had a significant effect on youths' cluster membership.

Adding Block 3 allowed analysis of the significant effects of social context variables, independent of child demographics and maternal psychiatric history. In this block, all three variables were significant predictors of cluster membership. Youth whose mothers reported more stressful life events in the social domain were less likely to be in the Anxious/Depressed cluster, compared with the Competent cluster. Adolescents whose mothers reported more available social support were significantly less likely to be in the Isolated Non-Conformist cluster. Finally, adolescents who reported a father in their lives were significantly less likely to be in the Average or the Delinquent/PeerOriented clusters, compared with the Academically Competent.

In Block 4, we examined the independent effect of the positive meaning of motherhood in predicting cluster membership. Although the variable was not a significant predictor of cluster membership overall, the comparison for the Delinquent/Peer-Oriented cluster versus the Academically Competent was - youth whose mothers more strongly endorsed the positive meaning of motherhood were less likely to be in the Delinquent cluster.

\section{DISCUSSION}

This study examined outcomes for adolescent offspring of mothers with a serious mental illness, using cluster analysis methodology and testing predictors of cluster membership from mother's clinical history and family contextual variables. A five-cluster solution was identified that was technically adequate, in that the smallest between-cluster distance was greater than its within-cluster dispersion. The clusters could be meaningfully described, and cluster differences were found on many variables external to those in the cluster analysis.

Congruent with other research results on mental health problems of adolescents of parents with mental illness (Beardslee 
et al., 1993; Rutter \& Quinton, 1987), we found one cluster (Anxious/Depressed), about $15 \%$ of the sample, that reported a high number of symptoms. These youth also had problems in school and reported feeling more hassled by the social environment. Some studies have found significantly more conduct problems in adolescent offspring of parents with mental illness (Boyle \& Pickles, 1997). Congruent with such findings, our study identified a cluster of students, Delinquent/ Peer-Oriented, who self-reported high levels of nonnormative behaviors (including police contacts) and deviant peer values. They also had lower school performance as indicated by school grade reports, as well as self-reported feelings of attachment and orientation to school and selfreported ability to solve problems. This cluster comprised more than a quarter of the sample. The largest cluster of adolescents, including $31 \%$ of the sample, demonstrated a high level of competence. These results are similar to those reported by Garber and Little (1999), who found that about $28 \%$ of children of depressed mothers were high functioning and without psychopathology. Like our Competent cluster, their group of adolescents scored low on symptom indicators and on behavior problems and high on positive coping and school competence.

Our cluster analysis results increased understanding of the heterogeneity of the target population by identifying two additional clusters. One of these clustersAverage, Adult-Oriented Youths comprised somewhat more than a quarter of the sample. Their scores in the domains of school functioning, symptomatology, and peer relationships were about at the median for the sample. They reported low environmental stressors, good academic work habits, and lew behavior problems. The cluster analysis also identified a much smaller group of students (about $5 \%$ ) with a somewhat unusual pattern of scores; we labeled this cluster Isolated NonConformists. Of greatest concern were their extremely low scores on peer involvement and social competence and very high reporting of peer deviant values.

The usefulness of the cluster analysis can also be seen by contrasting our clus- ter results with measures of central tendency for our sample. Means for the anxiety and depression measures (8.21 and 8.25 , respectively) are comparable to or even somewhat lower than those of youth from the general population. For example, on the Children's Depression Inventory (CDI; Kovacs, 1992) measure of depression, Aneshensel \& Sucoff (1996) reported $M=10.18(S D=7.80)$ in a teen sample with a mix of ethnicitics and SES levels; DuRant, Cadenhead, Pendergrast, Slavens, and Linder (1994), with a lowSES African American sample, reported $M=7.8(S D=6.0)$; Inderbritzen-Nolan and Walters $(2000)$, with a sample of 2,937 high school students who were mostly White and predominantly blue collar from a Midwest state, reported $M=$ 9.49 (SD = 7.22). On the Revised Children's Manifest Aniety Scale (RC-MAS; Cole, Hoffman, Tram, \& Maxwell, 20(0)), Weist, Paskewitz, Jackson, and Jones (1998), with a predominantly African American low-income school sample, reported mean anxiety for boys $M=8.5$ $(S D=5.1)$ and girls $M=10.6(S D=6.1)$; Inderbritzen-Nolan and Walters (2000) reported $M=8.93(S D=5.64)$ for their sample. Thus, from the overall descriptive statistics, it would appear that the adolescent offspring of our sample of mothers with mental illness are typical of other high school populations. However, the cluster analysis revealed that descriptive statistics, on the sample overall, obscure the fact that about $1.5 \%$ of the adolescents had anxiety and depression scores much higher than the means reported above, in fact, higher than the suggested clinical cut score of 15 for depression on the CDI (Liss, Phares, \& Liljequist, 2001) and close to the clinical cut score of 20 on the RC-MAS (Dadds, Spence, Holland, Barrett, \& Laurens, 1997; Hodges, 1990).

Thus, the clustering of multiple variables from major life domains served the intended purpose of identifying subgroups with distinct characteristics and demonstrating the heterogeneity of the entire sample. The cluster analysis also served to uncover heterogeneity within clusters across outcome domains. That is, while evidencing problems in some domains, several clusters displayed strengths in oth- ers (e.g., the Delinquent/Peer-()riented cluster showed high levels of peer involvement as well as social and interpersonal competence and a higher pereentage working than several other clusters). These findings indicate the importance of including strengths-oriented measures in descriptive studies of at-risk populations.

The cluster analysis results also provided some sense of the extent to which mothers with mental illness had adolescent offspring with serious problems in behavior or symptomatology. We found that about half of our sample fell into one of the problem groups, confirming that these adolescents are, indeed, at risk. However, congruent with the literature on resilience and contrary, perhaps, to some clinicians' assumptions, the majority of adolescents reported functioning competently, overall, at average or aboveaverage levels.

We also found gender dilferences across the clusters. These seem typical ol those found in many adolescent samples (i.c., girls constituted the minority in the Delincuent/Peer-Oriented cluster and the majority in the Anxious/Depressed cluster). It is interesting to note that there were no race differences associated with the five identified clusters, although the total sample size and perentage of Alrican American and White youth were adequate for comparison purposes. It is, of course, possible that more fine-tuned racial dilferences were not discovered and that future rescarch with measures from multiple perspectives might uncover such differences.

\section{Predictors of Cluster Membership}

We examined the relationship of cluster membership and variables identilied from the literature as predictors of children's resiliency. Overall, social contexlual variables showed more and stronger relationships with cluster assignment than did mothers' clinical characteristics. Cluster assignment was not signilicantly related to mothers' diagnoses or hospitalizations or to years of maternal separation. Drug/ alcohol abuse history was significantly related to cluster membership, with the 
Delinquent-Peer/Oriented cluster having molhers who reported a more problematic maternal history of use of substances. This is congruent with other research (Johnson \& Leff, 1999), wherein parental drug/ alcohol use is a strong predictor of adolescent conduct problems and substance use.

The variables from the family context domain that significantly related to cluster assignment are very similar to those glten identified as predictors of resiliency (c.g., support from a particular adult figure). A relationship with cluster assignment was also found for the measure of the total positive support mothers had available to them. In terms of Stressful Social Life Events, mothers of adolescents in the Anxious/Depressed cluster reported experiencing fewer of these. However, we suggest that this finding may actually rellect the lack of connectedness of these mothers; that is, if relationships are few, then the negative effects of relationship changes will be less frequent. Other literature on families with mental illness stress the importance of children having access 10 resources and supports beyond the mother to serve as an external anchor against her likely instability and inconsislent parenting (Mowbray \& Oyserman, 2003). Our results seem congruent with this conclusion. Contrary to expectations, cluster membership showed no relationship with adjusted income, possibly due 10 a restricted range on this variable in this sample, in which initially about twothirds of the mothers were living below the poverty level.

\section{Implications for Treatment and Research}

In line with the rescarch literature on prevention of mental health problems and promotion of well-being and mental health (Luthar el al., 2000), we found that resilience is multidimensional: Whereas one of the clusters appeared to be functioning in a highly competent manner in all domains, another cluster was mostly average across multiple measures. In three other clusters, there was evidence of functioning problems, but not in all domains. Kellam, Koretz, and Moscicki (1999) rec- ommended that preintervention risk research should analyze clusters of risk factors at the personal level, rather than just the variable level. That is, they noted that it was important to search for combinations of factors and their impacts rather than assessing single variables. Further, they recognized that among different subgroups, a given intervention may be differentially successful. Experience from prevention demonstrations supports the conclusion that any one intervention cannot assure positive outcomes for all individuals from an at-risk population; rather, for some individuals with multiple risk factors, several sequential or simultaneous interventions may be necessary. Prevention rescarch identifying subgroups within at-risk populations and the combinations of risk factors represented is thus appropriate and important for preventive interventions to effectively target subgroups at risk.

Replication of the current findings in other samples is needed to support the generalizability of our results. If the present results were replicated, they would have significant implications for planning prevention and treatment services for adolescent children of mothers with serious mental illness. The results indicate that only about $15 \%$ of these children may be in need of clinical treatment and/or medication (the Anxious/Depressed cluster). Some of the children (c.g., Delinquent/ Peer Oriented) have problems that may need other services (e.g., adult mentors and role models, assertiveness training to avoid peer influences). Still other adolescents (Isolated Non-Conformists) might benefit from interpersonal and social competence training or from having older adolescent or adult role models. The Average Adult-Oriented Youths might require periodic support and monitoring, to cnsure that they continue on a positive trajectory, especially those who are younger or score below average on multiple variables, including having no father attachment.

\section{Limitations}

This study did provide a number of improvements in sample size and composition and analytic methods compared to previous research. Although many measures were self-report, most involved concrete questions about behaviors and events (e.g., having police contacts) and were administered by trained interviewers in the adoleseent's home setting to maximize validity and reliability. However, limitations to this study should be recognized. First, even though the sample was larger than in most previous studies, power was adequate only for moderate-to-large cluster differences; the sample size was not sufficient to identify small differences or to test comparisons involving the smallest cluster. The sample of mothers was drawn from existing caseloads of public mental health agencies. Results could be quite dissimilar for adolescents whose mothers are not in treatment. Further, the settings were primarily outpatient, rather than residential or inpatient, implying that this group of mothers may have been somewhat higher functioning than would be typical of women with serious mental illness overall. Also, at study intake, all women had to have some care responsibilities for at least one minor child, although about a quarter had previously lost custody of one or more of their children. The results, therefore, cannot be generalized to children who were no longer in their mothers' care at adolescence. Finally, the population is drawn primarily from an urban area in the Midwest and is predominantly minority and low income. We attempted to find data on our measures from the literature on comparative groups of nonidentified adolescents. However, this was not possible in most cases. Thus, a limitation of the study is the lack of a normative comparison group of adolescents from the same geographical area. And, although we failed to find any racial/ ethnicity differences, these results will not necessarily gencralize to populations with much higher-income levels or samples with even greater cultural diversity (e.g., involving Latinas, Asian Americans).

We urge more rescarch on this topic using the same or similar paradigms and populations that are different, but large enough to permit use of clustering techniques. Ideally, the sample should be obtained from a large urban school system and thus permit better access to and use of 
reliable and comparable measures from school records and teacher ratings (c.g., achievement test scores, IQ, extracurricular participation, discipline and conduct problem indicators). Also, the study could be improved if longitudinal data could be collected on adolescent outcomes over time, to include all school records. This would permit examination of variations in adolescent trajectories over time. Finally, although it would be extremely challenging, attempts should be made to include adolescents whose parents have a serious mental illness but who are not currently receiving treatment.

\section{About the Authors}

CAROL T. MOWBRAY, PhD, is a professor in the School of Social Work and an associate professor in the Department of Psychology, at the University of Michigan, where she also directs the Center for Research on Poverty, Risk and Mental Health. Her research interests focus on psychiatric rehabilitation and recovery for adults with serious mental illnesses, especially supported education, parenting, and consumers as providers. DEBORAH BYBEE, PhD, is an associate professor of ecological/community psychology at Michigan State University. Her primary focus is on using statistical methodology to answer complex, real-world research questions. DAPHNA OYSERMAN, PhD, is a professor in the Department of Psychology and in the School of Social Work at the University of Michigan, where she is also a research scientist in the Research Center for Group Dynamics of Michigan's Institute for Social Research and director of the Michigan Prevention Research Training Program. PAULAALILN-MEARES, MSW, $\mathrm{PhD}$, is dean and the Norma Radin Collegiate Professor of Social Work at the School of Social Work at the University of Michigan. She is co-principal investigator for the NIMH Center for Research on Poverty, Risk, and Mental Health. PETER MAcFARLANE, BA, is a research associate in the School of Social Work at the University of Michigan, Center for Research on Poverty, Risk and Mental Health. His interests include mental health, mental health services, and rescarch methodology. TAMERA HART-JOHNSON, MS, is a research associate at the Institute for Social Research at the University of Michigan. She is the research coordinator for the Pathways for Youth Program. Her work focuses on adolescent identity and academic achievement. Address: Carol T.
Mowbray, University of Michigan School of Social Work, 1080 South University, Amn Arbor, MI 48109-1106; e-mail: cmowbray@ umich.edu

\section{Authors' Note}

This research was funded in part through NIMH Grant No. R01 MH57495 to the University of Michigan, Institute for Social Research and Grant No. R01 MH54321 to the Universily of Michigan, School of Social Work.

\section{References}

Achenbach, T. M. (1991). Manual for the Youth Self-Report and 1991 profile. Burlington: University of Vermont Department of Psychiatry.

Aneshensel, C. S., \& Sucoff, C. A. (1996). The neighborhood context of adolescent mental health. Joumal of Health \& Social Behar ior 37(4), 293-310.

Arbelle, S., Magharious, W., Auerbach, J G., Hans, S. L., Marcus, J., Styr, B., et al. (1997). Formal thought disorder in offspring of schizophrenic parents. Israd Journal of Psychiatry and Related Sciences. 34(3), 210-221.

Barrera, M. (1986). Distinctions between social support concepts, measures, and models. American Joumal of Community Psychology, 14(4), 413-45.

Bartholomew, D. J., \& Knott, M. (1999). Latent variable models and factor analysis (2nd ed.). London: Arnold.

Beardslee, W. R., Keller, M. B., Lavori, P. W., Staley, J., \& Sacks, N. (1993). The impact of parental affective-disorder on depression in offspring: A longitudinal follow-up in a nonreferred sample. Joumal of the American Academy of Child and Adolescent Psychiatry, 32(4), 723-730.

Beardslee, W. R., Versage, E. M., \& Gladstone. T. R. G. (1998). Children of affectively ill parents: A review of the past 10 years. Journal of the American Academy of Child and Adoleseent Psychiatry, 37(11), 1134-1141.

Billings, A. G., \& Moos, R. H. (1983). Comparisons of children of depressed and nondepressed parents: A social-environmental perspective. Journal of Abnormal Child Psychology, I/(4), 463-486.

Blashfield, R. K., \& Aldenderfer, M. S. (1988). The methods and problems of cluster analysis. In J. R. Nesselroade \& R. B. Cattell (Eds.), Handbook of multivariate experimental psychology (2nd ed.; pp. 447-473). New York: PIcnum Press.
Boyle, M. H., \& Pickles, A. R. (1997). Influence of maternal depressive symptoms on ratings of childhood behavior. Jomrnal of Alnormal Child Piwchology, 25(5), 399412.

Brugha, T. S., \& Cragg, D. (1990). 'The list of threatening experiences: The reliability and validity of a brief life events questionnaire. Acta Psychiatricaseandinavica, 82, 77-81.

Buka, S. L., Selner-O'Hagan, M. B., Kindlon, D. J., \& Earls, F. J. (1996). My exposure to violence and my childs expostre to violence. Boston: Human Development in Chiago Neighborhoods Project.

Cernkovich, S. A., \& Giordano, P. C. (1992). School bonding, race, and delinquency. Criminology, 30(2), 261-291.

Chang, K. K. D., Steiner, H., \& Ketter, T. A. (2000). Psychiatric phenomenology of child and atdolescent bipolar of fspring. Jomnal of the American Academy of Child and Adolescemt Psychiatry 39(4), 453-460.

Cohen, J. (1988). Statistical power andysisfor the behavional sciences (2nded.). Hillsdale, NJ: Erlbaum.

Cole, D. A., Holfman, K., Tram, J. M.. \& Maxwell, S. E. $(2000)$ ). Structural differences in parent and child reports of children's symptoms of depression and anxiety. Psychological Assessmem, 12(2), 174-185.

Dadds, M. R., Spence, S. H., Holland, D., Barrett, P. M., \& Laurens, K. (1997). Early intervention and prevention of anxiely disorders: A controlled study. Jommal of Consulting and Clinical Psychology. 65, 62763.5.

DuRant, R. H., Cadenheald, C., Pendergrast, R. A., Slavens, G., \& Linder, C. W. (1994). Factors associated with the use of violence among urban black adolescents. Anerican Journal of Public Health, 84(4), 612-617.

Eccles, J. (1995). Wave 3 scale dictionary for the student construct cluster: MacArthur Adolescent Network Study of Parent Involvement and Family Management in Prince George's County. Ann Arbor: Universily of Michigan.

Elliot, D. S., Huizinga, D., \& Morsc, B. (1985). Explaining delinquency and drug use. Beverly Hills, CA: Sage.

Erlenmeyer-Kimling, L.. Adamo, U. H., Rock, D., Roberts, S. A., Bassett. A. S., Squireswheeler, E, et al. (1997). The New York High-Risk Project: Prevalence and comorbidity of Axis I disorders in offspring of schizophrenic parents: $\triangle 25$-year follow-up. Archives of General Psychiatry, 54(12), $1096-1102$

Finn, J. D., Pannorzo, (s. M., \& Voelkl, K. E. (1995). Distuptive and inattentive with- 
drawn behavior and achievement among 4th-graders. Elementary School Jounal. $9.5(5), 421-434$

Ireedman. B. J., Rosenthal, L., Donahue, C. P.. Schlund, D. G., \& McFall, R. M. (1978). A social-behavioral analysis of skill deficits in delinquent and nondelinquent adolescent boys. Joumal of Consulting \& Clinical Psychology, 46(6), 1448-1462.

(iames, P. A., Keselman, H. J., \& Rogan, J. C. (1981). Simultaneous pairwise multiple comparison procedures for means when sample sizes are unequal. Psychological Bullotin, 90, 594-598.

( iarber, J., \& Little, S. (1999). Predictors of competence among offspring of depressed mothers. Journal of Adolescent Research, 1.4(1), 44-71.

(iarmezy, N. (1987). Stress, competence, and development: Continuities in the study of schizophrenic adults, children vulnerable to psychopathology, and the search for stressresistant children. American Journal of Orthopsychicatry, 57(2), 159-174.

(iarmezy, N. (1993). Vulnerability and resilience. In D. C. Funder, R. D. Parke, \& C. 'Tomlinson-Keasey (Eds.), Studying lives through time: Personality and development (pp. 377-398). Washington, DC: American Psychological Association.

Gigoroiu-Servanescu, M., Christodorescu, D., Totoescu, A., \& Jipescu, 1. (1991). Depressive disorders and depressive personality tratits in offspring aged 10-17 of bipolar and of nomal parents. Journal of Youth and Adolescence, 20(2), 135-148.

Goodman, S. H., \& Brumley, E. (1990). Schizophrenic and depressed mothers: Relational deficits in parenting. Developmental Psychology, 26(1), 31-39

I lammen, C., Gordon, D., Burge, D., Adrian, C.. Jaenicke, C., \& Hiroto, D. (1987). Maternal affective disorders, illness, and stress: Risk for children's psychopathology. American Journal of Psychicatry, 144(6), 736741.

Hammen, C. (1997). Children of depressed parents: The stress context. In S. A. Wolchik \& 1. N. Sandler (Eds.), Handbook of children's coping: Linking theory and intervention (pp. 131-.157). New York: Plenum Press.

Hancock, G. R., \& Klockars, A. J. (1996). The quest for alpha: Developments in multiple comparison procedures in the quarter century since Games (1971). Review of Educational Research, 60(3), 269-306.

Harter, S. (1988). Self-pereeption profile for adolescents. Denver, $\mathrm{CO}$ : University of Denver.
Hodges, K. (1990). Depression and anxiety in children: A comparison of self-report questionnaires to clinical interview. Psychological Assessment, 2, 376-381.

Hosmer, D. W., Jr., \& Lemeshow, S. (2000). Applied logistic regression (2nd ed.). New York: Wiley.

Inderbritzen-Nolan, H. M., \& Walters, K. S. $(2000)$. Social anxiety scale for adolescents: Normative data and further evidence of construct validity. Journal of Clinical Child Psychology, 29(3), 360-71.

Jaccard, J., \& Wan, C. K. (1996). LISREL approaches to interaction effects in multiple regression (quantitative applications in the social sciences No. 114). Thousand Oaks, CA: Sage.

Jellinek, M. S., \& Snyder, J. B. (1998). Depression and suicide in children and adolescents. Pediatrics in Review, 19(8), 255-264.

Johnson, J. L., \& Leff, M. (1999). Children of substance abusers: Overview of research findings. Pediatrics, $103(5)$, 1085-1123.

Kellam, S. G., Koretz, D., \& Moscicki, E. K. (1999). Core elements of developmental epidemiologically based prevention research. American Journal of Community Psychology, 27(4), 463-482.

Kovacs, M. (1992). Children's Depression Imentory manual. North Tonawanda, NY: Multi-Health Systems.

Lapalme, M., Hodgins, S., \& LaRoche, C. (1997). Children of parents with bipolar disorder: A meta-analysis of risk for mental disorders. Canadian Journal of Psychiatry, $12(6), 023631$

Iiss, H., Phares, V., \& Liljequist, L. (2001). Symptom endorsement differences on the Children's Depression Inventory with children and adolescents on an inpatient unit. Jounal of Personality and Assessment. $76(3), 396-411$.

Long, J. S. (1997). Regression models for cat egorical and limited dependent variables (advanced quantitative techniques in the social sciences series No. 7). Thousand Oaks, CA: Sage.

Luthar, S. S., Cicchetti, D., \& Becker, B. $(2000)$. The construct of resilience: A critical evaluation and guidelines for future work. Child Development, 7I(3), 543-562.

Masten, A. S., Hubbard, J. J., Gest, S. D., Tellegen, A., Garmezy, N., \& Ramircz, M. (1999). Competence in the context of adversity: Pathways to resilience and maladaptation from childhood to late adolescence. Development and Psychopathology, $/ /(1), 143-169$.
Mowbray, C. T., \& Oyserman, D. (2003). Families with parental mental illness, adolescence. In T. P. Gullotta \& M. Bloom (Eds.), Encyclopedia of primary prevention and health promotion (pp. 471-479). New York: Kluwer Academic/Plenum.

Mowbray, C. T., Oyserman, D., \& Bybee, D. (2000). Mothers with scrious mental illness. New Directions for Mental Health Services, $88,73-91$.

National Institute of Mental Hcalth. (1980). Diagnostic Interview Schedule (DIS). Rockville, MD: Author.

National Longitudinal Study of Adolescent Health. (1998). Retrieved August 30, 2004, from http://www.cpc.unc.edu/projects/ codebooks

Nicholson, J., Nason, M. W., Calabresi, A. O., \& Yando, R. (1999). Fathers with severe mental illness: Characteristics and comparisons. American Journal of Orthopsychiatry, 69(1), 134-141

Oyserman, D. (2003). Depression during the school-aged years. In P. Allen-Meares \& M. Fraser (Eds.), Intervention with children \& adolescents (pp. 264-281). New York: Allyn \& Bacon.

Oyserman, D., Bybee, D., Mowbray, C. T., \& Kahng, S. (in press). Parenting selfconstruals of mothers with a serious mental illness: Efficacy, burden and personal growth. Journal of Applied Social Psychology.

Oyserman, D., Mowbray, C. T., Allen-Meares, P. A., \& Firminger, K. B. (2000). Parenting among mothers with a serious mental illness. American fournal of Orthopsychiatry, 70(3), 296-315.

Radke-Yarrow, M., \& Klimes-Dougan, B. (2002). Parental depression and offspring disorders: A developmental perspective. In S. H. Goodman \& I. H. Gotlib (Eds.), Children of depressed parents (pp. 155-174). Washington, DC: American Psychological Association.

Rutter, M., \& Quinton., D. (1987). Parental mental illness as a risk factor for psychiatric disorders in childhood. In D. Magnusson \& A. Ohman (Eds.), Psychopathology: An interactional perspective (pp. 199-219). San Diego: Acadcmic Press.

Samaan, R. (1998). The influences of race, ethnicity and poverty on the mental health of children. Journal of Health Care for the Poor and Underserved, 11, 100-110.

Scherer, D. G., Melloh, T., Buyck, D., Anderson, C., \& Foster, A. (1996). Relation between children's perceptions of matcrnal mental illness and children's psychological 
adjustment. Joumal of Clinical Child Psychology, 25(2), 156-169.

Seidman, E., La Rue, A., Aber, J. L., Mitchell, C., Feinman, J., Yoshikawa, H., et al. (1995) Development and validation of adolescent perceived microsystem scales: Social support, daily hassles, and involvement. American Joumal of Community Psychology, 23(3), 355-388

Sneath, P. H. A., \& Sokal, R. R. (1973). Numerical taxomomy: The principles and practice of mumerical classification. San Francisco, CA: Freeman.

Streiner, D. L. (2003). Being inconsistent about consistency: When coefficient alpha does and doesn't matter. Joumal of Personality Assessment, 80(3), 217-222.

Su, S. S., Hoffmann, J. P., Gerstein, D. R., \& Johnson, R. A. (1997). The effect of home environment on adolescent substance use and depressive symptoms. Jommal of Drug Issues, 27(4), 851-877.

Tannenbaum, L., \& Forehand, R. (1994). Maternal depressive mood: The role of the fa- ther in preventing adolescent problem behaviors. Behaviour Research and Therapy. 32(3), 321-325.

Thomas, A. M., Forehand, R. \& Neighbors, B. (1995). Change in maternal depressive mood: Unique contributions to adolescent functioning over time. Adolescence, 30(117), $43-52$.

U.S. Census Bureau. (1996). Poverty thresholds in 1996, by size of family and number of related children under 18 Years. Retrieved November, 14, 2001, from http:/www. census.gov/hhes/poverty/threshld/thresl196. html

Vermunt, J. K., \& Magidson, J. (2002). Latent class cluster analysis. In J. A. Hagenatars \& A. L. McCutcheon (Eds.), Applied latent class analysis (pp. 89-106). Oxford, UK: Cambridge University.

Wals, M., Hillegers, M. H. J., Reichart, C. G.. Ormel, J., Nolen, W., \& Verhulst, F. C. (2001). Prevalence of psychopathology in children of a bipolar parent. Journal of the American Academy of Child \& Adolescent Prychiatry, 40(9), 1091-1102.
Warner, V., Weissman, M. M., Mufson, L., \& Wickramaratne, P. J. (1999). Grandparents, parents, and grandchildren at high risk for depression: A three-generation study. Jomllnat of the American Academy of Child and Adolescen Psychiatry 38(3), 289-296.

Weissman, M. M., Leal, P. J., \& Bruce, M. L. (1987). Single parent women: A community study. Social Psychiatry, 22(1), 29-36.

Weist, M. D., Paskewitz, D. A.. Jackson, C.Y., \& Jones, D. (1998). Self-reported delinquent behavior and psychosocial functioning in inner-city teenagers: $A$ brief report. Child Psychiatry \& Human Development, 28(4), 241-248.

Wickramaratne, P. J., \& Weissman. M. M. (1998). Onset of psychopathology in offspring by developmental phase and parental depression. Jommal of the American Areatemy of child and Adolescent Psychiot)y. 37(9), 933-942.

Wilcox, R. R. (1987). New statistical procederes for the wocial sciences: Modern soltetions to basic problems. Hillsdale, NJ: Virlbaum.

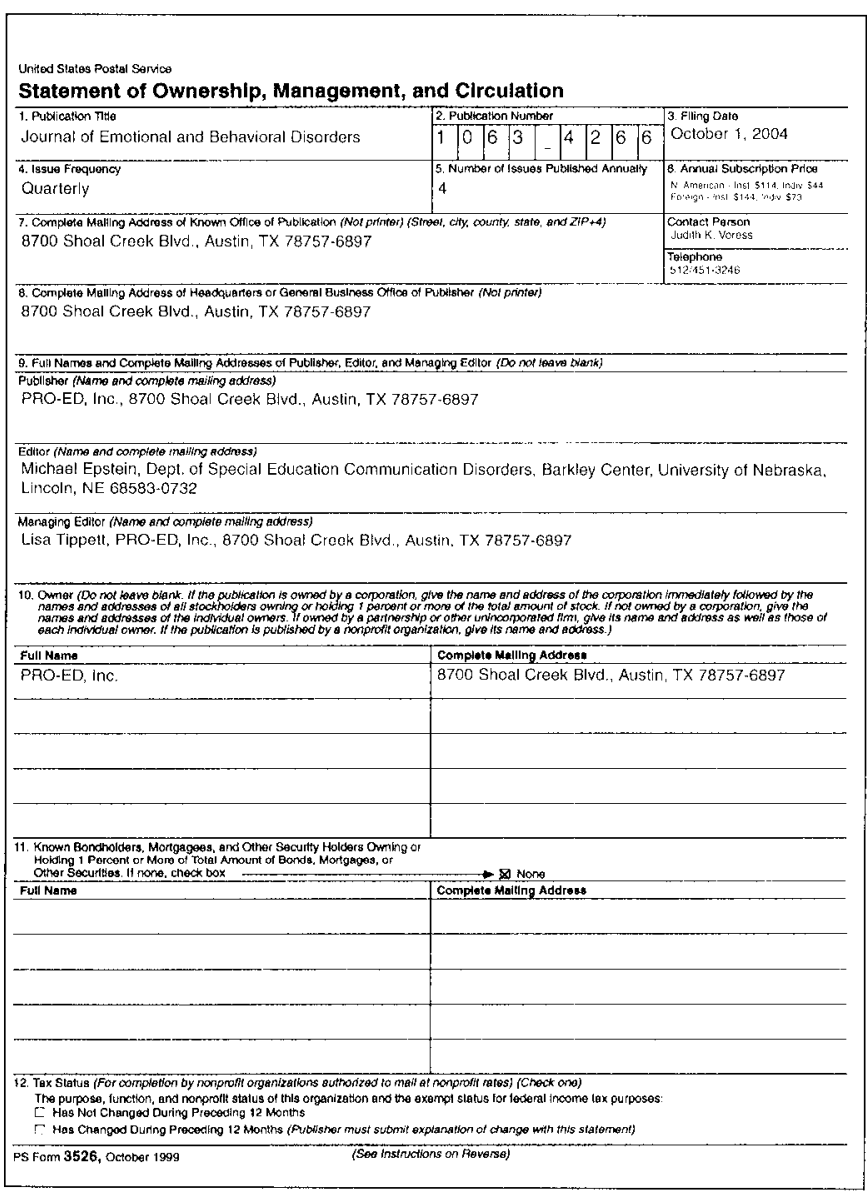

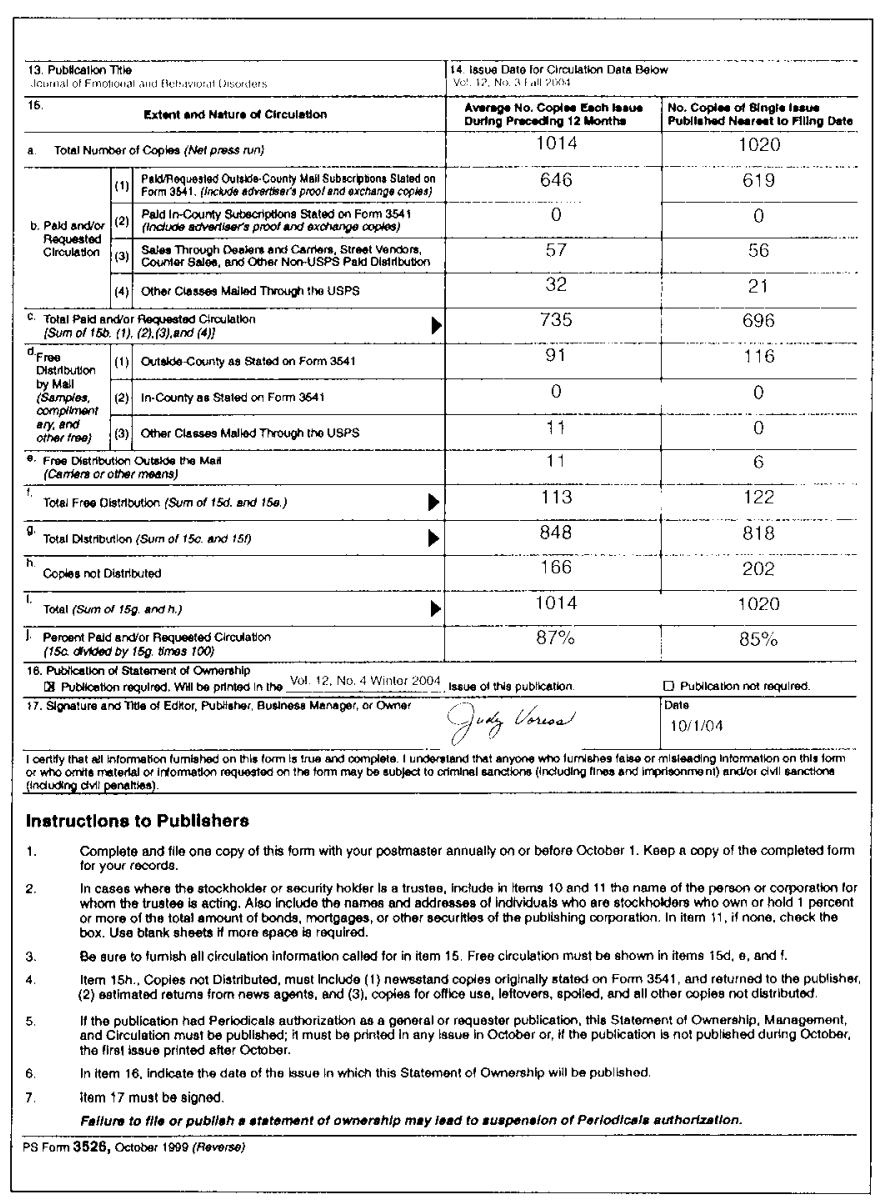

